\title{
Innovations during COVID-19 pandemic: trends, technologies, prospects
}

\author{
Natalia Serbulova ${ }^{*}, 1$, Tatyana Morgunova ${ }^{1}$, and Galina Persiyanova ${ }^{1}$ \\ ${ }^{1}$ Don State Technical University, sq. Gagarina, 1, Rostov-on-Don, 344003, Russia
}

\begin{abstract}
The paper presents the mechanisms for adapting innovation processes in corporations in the context of COVID-19 and demonstrates technologies and solutions that can be applied to meet current challenges. Innovation can become the link in the company that will help to survive the crisis and open up opportunities for identification, analysis and testing new products and processes. The use of new technologies and openness to innovations can be a decisive factor for staying ahead of the competition in the future. The paper performs examples of successful startups/companies that were able to competently and timely rebuild their business, and provides examples of government initiatives that share their approaches and valuable tips on how to continue innovating even in the current unprecedented times. The research was based on the coronavirus' impact analysis on various industries using leading industry data sources, analytical reports, international indexes and indicators.
\end{abstract}

\section{Introduction}

In addition to the serious consequences for human health, an enormous burden on health systems and public budgets of countries around the world, the current situation with COVID-19 in the world has affected almost all economic sectors, not bypassing the innovation scope. According to the International Monetary Fund, the global economy is currently experiencing the worst recession, and for the first time negative growth rates are forecast for advanced economies (-6.1\%), emerging markets $(-1 \%)$ and developing countries $(-2.2 \%$ excluding China). The latest data show that GDP in China in the first quarter of 2020 fell by $6.8 \%$ in comparison with an increase of $6.1 \%$ in 2019 [1]. For more than 170 countries, per capita income is expected to fall, with cumulative losses in global GDP of around USD 9 trillion for 2020 and 2021 [2]. Since March 2020, low-income developing countries have been hit by an exceptional confluence of external shocks: a sharp contraction in real exports, lower export prices, especially for oil, less capital and remittances inflows, and reduced tourism receipts. The current situation calls for quick responses, fast learning, and innovative and holistic solutions to help countries accelerate their digital transformation.

Beyond the humanitarian tragedy of the COVID-19 pandemic, the virus is also having a growing impact on local economies and the global economy [3]. Fears surrounding the unforeseeable effects of COVID-19 have already significantly influenced the world's top

${ }^{*}$ Corresponding author: nserbulova@mail.ru 
economies and many economists are now forecasting recession [4]. A crisis such as the COVID-19 pandemic threatens the functioning and performance of business [5].

Research and consulting companies, as well as leading rating agencies, identify the key industries that COVID-19 has had the greatest impact on, both negative and positive. Board of Innovation analysts identify six barriers that arose due to COVID-19: geopolitical, macroeconomic, regulatory, technological, industrial, barriers related to behavioral changes, as well as cross-industrial changes caused by such barriers [6].

Table 1. Barriers and key factors caused by COVID-19.

\begin{tabular}{|c|c|}
\hline Barriers & Key factors \\
\hline Geopolitical & Border closure \\
\hline Macroeconomic & $\begin{array}{c}\text { Decline in aggregate demand, } \\
\text { accumulation of product stocks } \\
\text { Projects financing issues } \\
\text { Decrease in real income and } \\
\text { solvency of the population }\end{array}$ \\
\hline Regulatory & $\begin{array}{c}\text { Self-isolation (lockdown), social } \\
\text { distancing } \\
\text { Plants shutdown (ban on } \\
\text { conducting face-to-face activities) }\end{array}$ \\
\hline Technological & Supply Chain Disruption \\
\hline Industrial & Forced digitalization \\
\hline Behavior changes & $\begin{array}{c}\text { Increasing demand for certain } \\
\text { goods and services } \\
\text { Massive shift to online }\end{array}$ \\
\hline
\end{tabular}

Oil and gas industry, airlines, tourism sector, industrial production, construction and real estate, banks, retail trade, restaurant and hotel business were extremely negative affected. The industries suffered primarily from the borders closure and implementation of a self-isolation regime, the need to close production facilities and enterprises to ensure social distance, and, as a result, a dramatic drop in demand for goods and services. For example, during the COVID-19 crisis, residents seldom drive their cars, so there is almost no business for gas stations [7]. The product characteristic of gasoline makes it almost impossible to be sold and fueled online.

At the same time, there are industries that discovered a growth trend during COVID-19 pandemic. This applies primarily to e-commerce, entertainment, and healthcare. This growth is achieved not only due to circumstances, such as increased demand for certain types of goods and services, but also due to the willingness of corporations for fast and effective key processes adaptation to new realities: a sufficient level of digitalization for moving business online, ability to adapt goods or services to the changing needs of customers and users, and the smooth functioning of supply chains [8]. Emerging economies are experimenting with new technologies and shaping the regulatory landscape, but digital access is still highly unequal. Large-scale investment in infrastructure and innovation is crucial for building an inclusive digital future.

\section{Impact of COVID-19 on the economy and industries}

World Economic Forum presented a map of transformational changes in the global economy and industries around the world. It shows how the impact of COVID-19 is spreading to various areas of our lives, and also outlines ongoing initiatives to combat the pandemic. Impact: workforce, trade, tourism, financial markets. Measures to combat COVID-19: government measures to support the economy, avoiding COVID-19 spread, finding a vaccine. Covid-19's assault has prompted a rapid mobilization of scientists, 
pharmaceutical companies and government officials to launch a variety of scientific initiatives to find an effective response to the virus.

The key task for many companies at the moment is the need to ensure not only the safety and health of employees, but also the continuity of operational processes. Almost all industries have had a negative impact on operational processes, with the exception of ecommerce. Even with industries showing strong declines, there are corporations that survive the crisis more easily than others. It was achieved through rapid response and adaptation, as well as the introduction of the necessary technologies that can ensure the continuity of operational activities in the context of mandatory social distancing.

In the current situation, all the existing barriers to innovation - budgets, processes, and talents have only become more acute and a truly narrow link in corporate innovation processes. However, corporations with established innovation processes and infrastructure, launched «pilot projects» aimed at sustainability, transparency and operational efficiency.

Nevertheless, the future looks promising for new sustainable multi-actor innovation hubs to support, connect, and enable businesses to recover and pivot beyond the COVID-19 pandemic. Innovations will focus on climate action, digitization, manufacturing, and sustainable food production, security, and waste mitigation. Pandemic has once again shown the importance and necessity of digital transformation. After all, it is companies that have actively implemented various digital technologies and solutions that have been able to survive the crisis more easily today than companies that are only at the beginning of the digital path. Authors analyzed changes in key economic sectors in terms of the COVID-19 impact on multinational corporations main processes - operating activities, interaction with end consumers and users, and supply chain management to identify the main factors for successful business transformation in the context of the crisis and corporate development after it (table 2).

Table 2. Impact of COVID-19 on key industries.

\begin{tabular}{|c|c|c|c|c|}
\hline Industry & $\begin{array}{c}\begin{array}{c}\text { Key } \\
\text { challenges }\end{array} \\
\end{array}$ & Case studies & $\begin{array}{c}\text { Type of } \\
\text { innovation }\end{array}$ & $\begin{array}{c}\text { Core } \\
\text { technology }\end{array}$ \\
\hline $\begin{array}{l}\text { Healthcare } \\
\text { Service }\end{array}$ & $\begin{array}{c}\text { Forced } \\
\text { digitalization } \\
\\
\text { Increasing } \\
\text { demand for } \\
\text { certain goods } \\
\text { and services }\end{array}$ & $\begin{array}{l}\text { Digitalization of healthcare } \\
\text { services in South Korea, } \\
\text { Singapore, Taiwan, the United } \\
\text { States, Germany, and other } \\
\text { developed countries [9-11]: } \\
\text { 1. Advanced digital contact } \\
\text { tracking solutions. } \\
\text { 2. Digitalized systems for } \\
\text { more efficient management of } \\
\text { in-patient beds and access to } \\
\text { medical care in a hospital } \\
\text { setting. } \\
\text { 3. Personalized online } \\
\text { screening. } \\
\text { 4. Personalized and predictive } \\
\text { public health management. }\end{array}$ & $\begin{array}{l}\text { Process } \\
\text { Product } \\
\text { System } \\
\text { Network } \\
\text { Channel }\end{array}$ & $\begin{array}{c}\mathrm{AI}, \mathrm{IoT}, 3 \mathrm{D} \\
\text { printing, deep- } \\
\text { tech }\end{array}$ \\
\hline E-commerce & $\begin{array}{l}\text { Increasing } \\
\text { demand for } \\
\text { certain goods } \\
\text { and services }\end{array}$ & $\begin{array}{l}\text { Robot-based delivery } \\
\text { applications. } \\
\text { Retailer JD has launched } \\
\text { robot-based delivery in China. } \\
\text { E-commerce giants, which } \\
\text { also develop e-health, have } \\
\text { increased their investments in } \\
\text { the industry. JD Health has } \\
\text { filled its platform with }\end{array}$ & $\begin{array}{l}\text { Process } \\
\\
\text { Product } \\
\text { System }\end{array}$ & $\begin{array}{c}\text { UAV } \\
\text { Robotics } \\
\text { AI/ML }\end{array}$ \\
\hline
\end{tabular}




\begin{tabular}{|c|c|c|c|c|}
\hline & & $\begin{array}{l}\text { pharmacies with no fee } \\
\text { charged. Chinese group } \\
\text { purchase operator Pinduoduo } \\
\text { tweaked its app to help people } \\
\text { living in the same gated } \\
\text { compound pool individual } \\
\text { orders into a group purchase. } \\
\text { The consolidated order would } \\
\text { then be delivered to the gate } \\
\text { of the community, received by } \\
\text { the community's designated } \\
\text { volunteers before being } \\
\text { distributed to individual } \\
\text { customers. }\end{array}$ & & \\
\hline $\begin{array}{l}\text { Entertainment } \\
\text { industry }\end{array}$ & $\begin{array}{c}\text { Increasing } \\
\text { demand for } \\
\text { certain goods } \\
\text { and services }\end{array}$ & $\begin{array}{l}\text { Content creation: ESPN and } \\
\text { Fox Sports have opened up } \\
\text { access to old content, } \\
\text { documentaries, e-sports, and } \\
\text { niche competitions. The NBA } \\
\text { has launched the possibility of } \\
\text { online streaming of NBA 2K } \\
\text { (video games). }\end{array}$ & $\begin{array}{c}\text { Customer } \\
\text { Engagement }\end{array}$ & $\begin{array}{l}\text { AR/VR } \\
\text { Esports }\end{array}$ \\
\hline $\begin{array}{l}\text { IT and } \\
\text { Telecom }\end{array}$ & $\begin{array}{c}\text { Increasing } \\
\text { demand for } \\
\text { certain goods } \\
\text { and services } \\
\text { Supply Chain } \\
\text { Disruption }\end{array}$ & $\begin{array}{c}\text { For costumers: } \\
\text { To ease the financial burden } \\
\text { on customers, Telecom } \\
\text { service providers waive } \\
\text { delayed payments, offer } \\
\text { flexible payment plans, stop } \\
\text { canceling service, and } \\
\text { temporarily provide } \\
\text { customers with unlimited } \\
\text { traffic. } \\
\text { For track \& trace: } \\
\text { Providing aggregated and } \\
\text { anonymous mobile phone } \\
\text { location data to government } \\
\text { agencies to analyze mobility } \\
\text { and infection risks. }\end{array}$ & $\begin{array}{c}\text { Network; } \\
\text { Product } \\
\text { System }\end{array}$ & $\begin{array}{c}\text { Big Data } \\
\text { AI }\end{array}$ \\
\hline $\begin{array}{l}\text { Industrial } \\
\text { production }\end{array}$ & $\begin{array}{c}\text { Border } \\
\text { closure } \\
\text { Supply Chain } \\
\text { Disruption } \\
\text { Self-isolation } \\
\text { and social } \\
\text { distance } \\
\text { Plants } \\
\text { shutdown }\end{array}$ & $\begin{array}{l}\text { Production lines fast } \\
\text { adaptation through } \\
\text { technology: Airbus prints } \\
\text { protective plastic masks using } \\
\text { 3D printing technologies. } \\
\text { Medical device makers and } \\
\text { car manufacturers like Ford } \\
\text { and GM have joined forces } \\
\text { for ventilators mass } \\
\text { production [10]. Dyson } \\
\text { started producing medical } \\
\text { equipment. }\end{array}$ & Process & $\begin{array}{l}\text { Industry 4.0: } \\
\text { IoT, 3D } \\
\text { printing, } \\
\text { blockchain, AI } \\
\text { and ML, UAV } \\
\text { etc. }\end{array}$ \\
\hline
\end{tabular}




\begin{tabular}{|c|c|c|c|c|}
\hline $\begin{array}{l}\text { Wholesale } \\
\text { and retail } \\
\text { trade }\end{array}$ & $\begin{array}{c}\text { Massive shift } \\
\text { to online } \\
\\
\text { Forced } \\
\text { digitalization } \\
\text { Self-isolation } \\
\text { and social } \\
\text { distance } \\
\text { Border } \\
\text { closure }\end{array}$ & $\begin{array}{l}\text { Self checkout and self-service } \\
\text { Alibaba and Zhongbai, one of } \\
\text { Hubei's largest retailers, built } \\
\text { a self-service store. }\end{array}$ & Process & $\begin{array}{l}\text { Robotics } \\
\text { Payments } \\
\text { Solutions } \\
\text { Self-checkout }\end{array}$ \\
\hline $\begin{array}{c}\text { Hotel and } \\
\text { Restaurant } \\
\text { business }\end{array}$ & 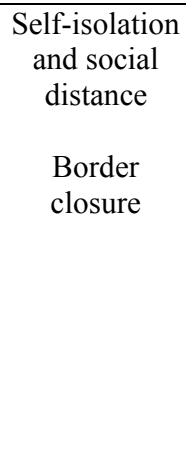 & $\begin{array}{l}\text { Expanding online presence, } \\
\text { focusing on content } \\
\text { marketing, and capturing the } \\
\text { audience. Double Tree by } \\
\text { Hilton revealed the secret } \\
\text { cookie recipe in social media } \\
\text { - 200k views and a lot of } \\
\text { responses as a result. } \\
\text { Maximum customer care, } \\
\text { enhanced sanitary measures: } \\
\text { Ottilia hotel in Copenhagen } \\
\text { has introduced self- } \\
\text { disinfection technology. }\end{array}$ & $\begin{array}{c}\text { Channel } \\
\text { Customer } \\
\text { Engagement } \\
\text { Product } \\
\text { Performance }\end{array}$ & $\begin{array}{l}\text { Martech } \\
\text { Big Data } \\
\text { Medtech }\end{array}$ \\
\hline Insurance & $\begin{array}{l}\text { The decline } \\
\text { of solvency } \\
\text { Forced } \\
\text { digitalization }\end{array}$ & $\begin{array}{l}\text { Ping An Insurance in China } \\
\text { has introduced a digital } \\
\text { platform that allows various } \\
\text { stakeholders to collaborate } \\
\text { (insurers, ambulance services, } \\
\text { hospitals, employers, mental } \\
\text { health consultants, and } \\
\text { others). This has helped the } \\
\text { company cope with the crisis } \\
\text { more effectively and support } \\
\text { some banks and insurers, also } \\
\text { this technology has enabled } \\
\text { employees, customers and } \\
\text { agents to be involved online } \\
\text { since the first days of the } \\
\text { COVID-19 outbreak. }\end{array}$ & $\begin{array}{l}\text { Channel } \\
\text { Network }\end{array}$ & $\begin{array}{c}\text { ML and AI } \\
\text { Big Data }\end{array}$ \\
\hline $\begin{array}{l}\text { Construction } \\
\text { and Real } \\
\text { estate }\end{array}$ & $\begin{array}{l}\text { Funding } \\
\text { problem }\end{array}$ & $\begin{array}{l}\text { VR technologies and } \\
\text { switching to online. } \\
\text { Evergrande Real Estate Group } \\
\text { has mobilized its offline sales } \\
\text { teams and encouraged them to } \\
\text { use virtual reality and social } \\
\text { media to better attract } \\
\text { customers. In addition, the } \\
\text { company changed its previous } \\
\text { non-refundable Deposit policy } \\
\text { to fully refund it, exclusively } \\
\text { for the online channel. Within } \\
3 \text { days, customers reserved } \\
47,540 \text { homes online, paying } \\
\text { a mini fee of } 3,000 \text { yuan. As a } \\
\text { result, the company's sales } \\
\text { reached } 44.73 \text { billion yuan } \\
\text { (\$6.4 billion) in February, up }\end{array}$ & $\begin{array}{c}\text { Customer } \\
\text { Engagements } \\
\text { Channel }\end{array}$ & $\begin{array}{c}\mathrm{VR} \\
\text { Digitalization }\end{array}$ \\
\hline
\end{tabular}




\begin{tabular}{|c|c|c|c|c|}
\hline & & 118 percent. & & \\
\hline $\begin{array}{l}\text { Transport, } \\
\text { Logistics and } \\
\text { Storage }\end{array}$ & $\begin{array}{c}\text { Border } \\
\text { closure } \\
\text { Supply Chain } \\
\text { Disruption }\end{array}$ & $\begin{array}{l}\text { Monitoring and control of } \\
\text { supply chains. TradeNetwork } \\
\text { has launched the } \\
\text { iTradeMarketplace platform } \\
\text { that allows suppliers, buyers, } \\
\text { and packaging companies to } \\
\text { get free access to information } \\
\text { about where «gaps» in supply } \\
\text { chains have occurred, for } \\
\text { quick response and closing of } \\
\text { supply chain needs. }\end{array}$ & $\begin{array}{c}\text { Network } \\
\text { Product } \\
\text { System }\end{array}$ & $\begin{array}{c}\text { AI Bockchain } \\
\text { SaaS } \\
\text { Platforms }\end{array}$ \\
\hline Tourism & $\begin{array}{c}\text { Border } \\
\text { closure }\end{array}$ & $\begin{array}{l}\text { Pack Up + Go | A Surprise } \\
\text { Travel Agency. Launch of the } \\
\text { Staycations product, which } \\
\text { allows you to organize a } \\
\text { «mini-trip» near your location } \\
\text { with a fully planned leisure, } \\
\text { schedule and logistics. }\end{array}$ & $\begin{array}{c}\text { Product } \\
\text { Performance }\end{array}$ & $\begin{array}{c}\text { AR/VR } \\
\text { Virtual } \\
\text { Assistants }\end{array}$ \\
\hline Bank System & $\begin{array}{l}\text { The decline } \\
\text { of solvency } \\
\text { Forced } \\
\text { digitalization }\end{array}$ & $\begin{array}{l}\text { Digital identity verification } \\
\text { technologies. HSBC has } \\
\text { launched a new Smart Mobile } \\
\text { Onboarding feature for } \\
\text { customers in mainland China. } \\
\text { The Bank allowed customers } \\
\text { across China to open accounts } \\
\text { in yuan via mobile phone and } \\
\text { became the first foreign Bank } \\
\text { to implement this service. } \\
\text { New customers will be able to } \\
\text { fill out and apply for an } \\
\text { appointment to open an } \\
\text { account online through HSBC } \\
\text { China WeChat Banking or } \\
\text { through their Internetbank. }\end{array}$ & $\begin{array}{c}\text { Channel } \\
\text { Customer } \\
\text { Engagement } \\
\text { Product } \\
\text { Performance }\end{array}$ & $\begin{array}{c}\text { ML and AI } \\
\text { Big Data }\end{array}$ \\
\hline Airlines & $\begin{array}{c}\begin{array}{c}\text { Decline in } \\
\text { demand }\end{array} \\
\text { Border } \\
\text { closure } \\
\text { Self-isolation } \\
\text { and social }\end{array}$ & $\begin{array}{l}\text { Airlines should prepare to } \\
\text { adapt their offers to new, } \\
\text { more inflated customer } \\
\text { requirements, while at } \\
\text { minimal cost, and also retain } \\
\text { customers during the } \\
\text { downturn. For example, } \mathrm{S} 7 \\
\text { Airlines has launched the }\end{array}$ & Service & $\begin{array}{c}\text { AI } \\
\text { Predictive } \\
\text { analytics } \\
\text { Chatbots } \\
\text { Salesforce } \\
\text { technologies }\end{array}$ \\
\hline
\end{tabular}




\begin{tabular}{|c|c|c|c|c|}
\hline & distance & $\begin{array}{l}\text { ability to earn miles just for } \\
\text { staying at home. }\end{array}$ & & \\
\hline Oil and Gas & $\begin{array}{l}\text { Decline in } \\
\text { demand } \\
\text { Supply Chain } \\
\text { Disruption }\end{array}$ & $\begin{array}{l}\text { Predictive Analytics for } \\
\text { remote monitoring. The } \\
\text { VROC platform with } \\
\text { predictive analytics using AI } \\
\text { provides its customers with } \\
\text { remote access to monitor the } \\
\text { state of oil rigs and receive } \\
\text { advance warnings to prioritize } \\
\text { maintenance, safely plan and } \\
\text { optimize production even with } \\
\text { limited on-site staff. }\end{array}$ & Process & $\begin{array}{c}\text { ML and AI } \\
\text { Predictive } \\
\text { analytics } \\
\text { Big Data }\end{array}$ \\
\hline
\end{tabular}

The research identified key messages of the digital transformation in the industries around the world: develop digital leadership and institutions; strengthen both digital and non-digital foundations of the digital economy; align digital economy strategy to support overall country development strategies; set sectoral transformation priorities in health, education, and essential public services; develop digital economy skills and capabilities; address poverty and inequality indicators early on at the diagnostic stage; engage underrepresented stakeholders and SMEs; support digital innovation and entrepreneurship to underpin adaptive-learning transformation strategies; mobilize demand and widespread adoption of promising applications and local innovations; and build platforms and culture for innovation and leaning [12]. To remain at the top, today's innovation champions must continue to invest in novel education and keep their countries open for business and open to the world. What we have seen from recovery packages strikes a healthy balance between the need to protect jobs and retain stability in the short run and the need for longer term changes (e.g. through digital transformation and fighting climate change).

\section{Technological innovations and new business models}

Flexibility of innovation processes makes it possible not only to quickly adapt to the current situation, but also to significantly improve performance. Creating and implementing the most up-to-date solutions allows companies to operate not just normally, but often with an increase in efficiency and productivity.

The current situation and new regulations create new customer needs, which leads to a review of the entire industries activities. It is no longer enough for companies to simply review their product range; they have to move on to fundamental changes that can only be achieved quickly by innovating. Moreover, coronavirus' influence accelerates the process of technology adoption and application in life [13]. If before each new product had to go through an adaptation period with a limited number of «early adopters» (the first user pool) and gradually increase market share by expanding user categories, now in many areas the «adoption curve» of technologies has moved sharply to the left, in particular in the direction of e-health and e-commerce. The ability to adapt quickly to these changes is especially critical today.

The main drivers for innovation in regular times are mainly access to new technologies and ability to launch new products/services. However, during the COVID-19 period, the 
main driver for innovation is the ability to reduce costs and introduce technologies aimed at production processes rapid adaptation.

COVID-19 has already demonstrated to the world the ability of people to unite around a single goal to defeat the disease and reduce the negative effect. The same thing happens in corporations: when employees see that digital transformation, innovation allows them to quickly adapt to current situations, stay afloat and continue to run a successful business, it increases their involvement in innovation processes. The question of the necessity and significance of digital transformation has not been asked for a long time. Thus, the current moment is ideal for finally resolving the issue with the innovative culture of employees. Online courses on intrapreneurship and open innovation in general can be a good tool, as well as subject courses to improve specific skills of employees: design thinking, product management, digital transformation, innovation project management, and etc.

There are many examples on how employees found breakthrough solutions that were successfully scaled to the entire production. There are also successful cases where unique technologies have been found outside and successfully integrated by corporations. Corporate innovations are often aimed at optimizing internal processes and are used extensively in such companies as Google, Amazon, Yandex. New ideas are born as a result of the initiative of employees, in the directions indicated by top management, and the company's processes are arranged in such way as to provide opportunities for their implementation. This approach may be particularly in demand in the current environment, when many companies reduce their budgets for searching for certain technologies.

The open innovation model is based on the search for new technologies in the market to solve the company's internal problems. As in the model of internal corporate innovation, the search directions are determined by the company's managers at different levels. By synthesizing the information obtained, the most important problems for the company are identified that need to be solved in a fairly short time (to avoid losing revenue or increasing costs), which do not have enough competencies or resources within the company to solve. In the current situation, many innovative processes that fit into this model had to be put on pause.

Technologies become a major driver of operation and adaptation for companies at this juncture. The range of solutions that are actively developing now is very wide, but we can distinguish the following 5 key areas: autonomous things; identification and tracking; automation; online engagement and entertainment; cybersecurity.

Man was a vulnerable link during the pandemic, which caused the mass introduction of robots and drones in various directions from delivery services to production. Moreover, the current situation can accelerate the adaptation of the regulatory framework for the implementation of these technologies. Autonomous delivery of goods by secure drones helps to speed up and reduce the cost of organizing the last mile of delivery for businesses with logistics component (e-commerce, food delivery, etc.).

Identification and tracking technologies play an important role in detecting and tracking the spread of the virus, as well as identifying potential contacts with the infected. It may soon become a standard to provide these technologies to any infrastructure facilities. Automated visual inspection systems can be used as a thermal imager in public places to identify people under quarantine and under medical supervision, as well as to track the spread of the virus.

Process disfunctions - supply chain disruptions, suspension of production due to the transition to remote operation - have proved the need for high-quality analytics and processes automation. It would open the way to advanced AI technologies, digital twins, and the industrial Internet of things [14-16]. Blockchain platforms can be used to create various industry-specific solutions to optimize business processes. One example of such solutions is an onboard data logger "white box», which includes a system for collecting, 
storing and processing information about the state and movement of transport and cargo based on blockchain, IoT and machine learning (ML) technologies.

Mass consumption of online content opens up opportunities for technologies that will allow to capture and engage the user. Augmented reality (AR) technologies are now able to get a big jump in development in all areas of application - from games and educational content to employee training. Software to work together with 3D models in VR can help to solve industrial problems in the fields of engineering, education and design. Such projects are a successful solution for organizing remote teamwork in VR for training, technical advice and presentations over the network. The advantages of the solution are a universal application that does not require converting CAD/BIM models to VR, as well as a variety of supporting VR devices: professional VR helmets and projection systems.

The massive switch to online has given a lot of new opportunities for cybercriminals. For example, the growth of phishing emails in the United States increased by more than $600 \%$. Oz Liveness on the Oz Forensics platform offers users of banking services a highquality solution for opening accounts, with high accuracy of identification and verification, which protects the personal data of customers and banks from fraud.

\section{Conclusions}

All the trends show the overwhelming potential of emerging technologies to help us improve the state of the world. Innovation is the process of turning new ideas into value, in the form of new products, services, or ways of doing things. It is deceptively complex, and goes beyond mere creativity and invention to include practical steps necessary for adoption. New innovations tend to build on earlier versions and, in turn, to lay foundations for others. It is now widely accepted that innovation fuels the majority of the world's long-term productivity and economic growth. Innovative companies significantly outperform noninnovators, in terms of both revenue and employment growth using the digital world as a source of ideas, creativity, and as raw material for their own unique contributions to global progress. Be it through the development of practical, affordable solutions such as delivery drones, or through innovative regulatory models for greater privacy and data protection, innovators are adopting new technologies to suit their specific needs and goals. Often, these ideas then cross borders and inspire entrepreneurs and consumers in other countries. This wealth of talent and ideas shows why it is so important to cooperate on a global scale. Innovation can be the link in a company that will help to survive the crisis and open up opportunities for identifying, analyzing, and testing new products and processes. The use of new technologies and openness to innovation can be a crucial factor for outperforming competitors in the future.

\section{References}

1. National Bureau of Statistics of China Preliminary accounting results of GDP in the first quarter of $2020 \quad$ (Last accessed 15.08.2020) http://www.stats.gov.cn/tjsj/zxfb/202004/t20200417_1739602.html

2. World Economic Outlook: The Great Lockdown https://www.imf.org/en/Publications/WEO/Issues/2020/04/14/weo-april2020\#Introduction (Last accessed 15.08.2020)

3. N. Donthu, A. Gustafsson. J. Bus. Res. 117, 284-289 (2020) https://doi.org/10.1016/j.jbusres.2020.06.008

4. Andreas Kuckertz et al. JBV Insights, 13 https://doi.org/10.1016/j.jbvi.2020.e00169 
5. T. A. Williams, et al., Acad. Manag. Ann., 11, 733-769 (2017) doi: 10.5465/annals.2015.0134

6. Board of Innovation, Innovating in the Low Touch Economy (2020) URL: https://www.boardofinnovation.com/low-touch-economy/ (Last accessed 15.08.2020)

7. Finance.sina The sales of refined oil business at gas station dropped by more than $30 \%$ year-on-year in the first two months of 2020. http://finance.sina.com.cn/money/future/nyzx/2020-02-12/dociimxyqvz2234700.shtml. (Last accessed 15.08.2020)

8. B. Tronvoll, A. Sklyar, D. Sörhammar, C. Kowalkowski. Ind Market Manag., 89, 293$305(2020)$

9. C. J. Wang, C. Y. Ng, R. H. Brook, J Am Med Assoc, 323, 1341-1342 (2020)

10. Z. I. Attia, S. Kapa, et al., Nat Med, 25, 70-74 (2019)

11. R. Albergotti, F. Siddiqui, The Washington Post. https://www.washingtonpost.com/business/2020/04/04/ventilators-coronavirus-ford$\mathrm{gm} /$ (Last accessed 15.08.2020)

12. N. K. Hanna, J Innov Entrep, 9, 16 (2020) https://doi.org/10.1186/s13731-020-00129-1

13. G. Farrugia, R. W. Plutowski. Mayo Clinic Proceedings, 95, 1574-1577 (2020)

14. A. Kumar, et al., FGCS, 115, 1-19 (2020) https://doi.org/10.1016/j.future.2020.08.046

15. R. Vaishya, M. Javaid, I. H. Khan, A. Haleem, Diabetes Metab Syndr, 14, 337-339 (2020) https://doi.org/10.1016/j.dsx.2020.04.012

16. P. Sharma, et al., JBS, https://doi.org/10.1016/j.jbusres.2020.05.026

116, $\quad 188-192$

(2020) 